Criação 



\title{
A cabeça voraz
}

\author{
BETTY MINDLIN
}

$\mathrm{N}$

UM MITO TUPARI DE RONDÔNIA (1), uma mulher casada divide-se todas as noites. A cabeça parte em busca de carne e alimentos de outras malocas e aldeias; o corpo mutilado fica na rede, carinhosamente abraçado ao marido. De madrugada, supostamente saciada, a cabeça volta e cola-se ao próprio corpo.

O marido nada percebe, mas acorda com o peito ensangüentado, sem saber por quê. A mulher é boa esposa, faz uma chicha saborosa, sopa nutritiva que entre os Tupari é fermentada por um processo de mastigação, pelas mulheres, de um bocado de milho, cará, mandioca ou inhame. $\mathrm{O}$ que o marido não sabe é que, em vez de mastigar, ela costuma cortar um dos dedos e pingar sangue na sopa para fermentar.

Intrigados com o sangue no peito do rapaz, seus parentes resolvem ficar à espreita. Descobrem o corpo sem cabeça e o jogam numa fogueira. A cabeça, de longe, urra de dor, vem voando para colar-se ao corpo no meio das chamas e a mulher, inteira outra vez, toda queimada, vira bacurau, um engole-vento, e sai voando.

Vem nas noites seguintes, lamuriosa, chamar o marido. É agora um espírito malévolo, um Tarupá. Diz que o ama, pede-lhe que a acompanhe. Depois de hesitar, ele a segue, aprendem ambos a voar, vão para o reino do céu agarrandose a um cipó, atingem as alturas, onde passam a viver com os bacuraus. Estes são assustadores, sobrenaturais. O marido, ou a mulher-bacurau, vira uma estrela, perto das que chamamos Três Marias.

Os Tupari acreditam que quando o bacurau canta à noite é porque alguém vai morrer. Segundo a tradição, quando alguém é morto, assassinado, o bacurau sente o cheiro de sangue e desce para chupar seu sangue e comer a sua carne. O pássaro mítico, assim, seria carnívoro, ou chuparia sangue, embora os bacuraus, da família caprimulgidae, alimentem-se exclusivamente de insetos, e têm bocas enormes para apreender a comida em vôo (2), o que certamente é do conhecimento dos índios.

\section{A imagem psicológica}

Esta história espantosa dá o que pensar a quem a ouve pela primeira vez. 
Uma lição sobre a voracidade feminina, a gula excessiva - carnívora, embora alguns narradores falem apenas de produtos da roça. Uma mulher não-humana, esquisitíssima, para quem o sangue - assustador e perigoso sempre - não é problema, pois utiliza na alimentação da aldeia o sangue secreto do dedo, vampiro às avessas...

O bacurau, aprendendo a subir ao céu, liga a esfera terrestre, humana, à celestial, à do além, ao mundo aterrorizante dos espíritos, dos que anunciam a morte e vêm atrás de cadáveres. Aparece uma estrela - o que, muitas vezes nesses mitos, é resultado de mutilações. Desordem nas regras sociais, com uma sanguinária devoradora; nova ordem no mapa celestial, um astro surge.

\section{A imagem na ficção não-indígena}

Certamente este tema das narrativas orais indígenas impressiona porque não é comum, talvez mal exista na fição ou no imaginário mais conhecido das nossas publicações - o da literatura escrita - apesar de todas as histórias de horror, de crime, de espanto, apesar do terror da Revolução Francesa e da guilhotina, de Alice no País das Maravilhas.

Na mitologia grega, como em outras, há mutilações: Dionísios é um exemplo, despedaçado e sem identidade, a ponto de perder até mesmo a definição exata de qual é o seu sexo. Estamos habituados aos vampiros, às mulas-semcabeça, às górgonas, às cabeças invertidas que trocam de corpos, como num romance de Thomas Mann, aos contos fantásticos de Wells, Hoffmann e Poe não a cabeças ativas e autônomas com movimento próprio.

\section{A versão Macurap (3)}

A versão da mesma história entre os Macurap, um povo vizinho aos Tupari, dá uma virada intrigante. Num casal muito unido, a cabeça da mulher também sai a passeio todas as noites, ávida por caça, insatisfeita com a que o marido proficiente providencia. Dizem alguns que ela tinha tal quantidade de piolhos, impossíveis de matar, que seriam eles quem queriam carne e separavam sua cabeça do corpo.

O marido, desta vez, sabe o segredo - aparentemente aceita sem problemas a proximidade mutilada pela noite adentro, tolerante para com a independência feminina nesta forma tão incompreensível, tão anormal.

É a mãe da moça, ao chamar a filha de madrugada ainda em plena escuridão, para ir à roça numa colheita destinada a uma festa, quem descobre o corpo sem cabeça. Horrorizada, acusa o genro de matar a filha; ele nega, pede para esperarem a volta da cabeça aventureira, mas a família não acredita, enterra a 
moça-sem-cabeça. Quando a cabeça volta, não encontra seu complemento. Desesperada, cola-se ao ombro do marido.

Amam-se, mas a cabeça se torna insuportável, putrefata, em decomposição, mal cheirosa. O marido passa a ser um homem com duas cabeças, obedecendo ordens, alimentando a cabeça da esposa com uma quantidade nunca suficiente de carne. Para onde irá o alimento que a boca devora? Esta é a indagação do narrador. E daí é um trabalhão para livrar-se dela, do odor asfixiante. O caçador inventa um estratagema: dispõe, num moquém distante, muita caça para a mulher ir atrás; e enquanto ela se afasta, aliciada, o marido foge.

A cabeça, sozinha, fétida, passa a ser um Txopokod, espírito ameaçador que devora os homens como devorava a carne, até que um dia um guerreiro esperto, corajoso e veloz, consegue exterminá-la.

\section{Uma interpretação}

Na versão Macurap, assim, o bacurau é substituído pela cabeça grudenta. A mulher voraz é a que se agarra ao homem, colante, incômoda, outro tipo de excesso, de comportamento imoderado, outra lição sobre o que não deve ser e horroriza, mau cheiro insuportável; a amante supérflua, antes tão desejada, agora praga e tormento do qual é preciso se livrar.

Uma mulher moderna poderia ampliar as analogias, perguntando se a cabeça pensa - a voracidade poderia ser também intelectual, querer saber de tudo em toda parte, abraçar o mundo, apartar-se do papel doméstico e erótico de esposa noturna na rede? Não é o caso, provavelmente este não é um símbolo indígena. O engole-vento tem uma boca imensa, como que rasgada, a associação só pode ser com a gula ou com o sexo. A cabeça estaria no lugar da sexualidade, aventuras noturnas eróticas da esposa bem comportada durante o dia?

\section{A cabeça voadora, a lua e Macunaima}

O motivo da cabeça voadora tornou-se parte integrante e difundida da ficção brasileira a partir de Macunaima, que contém um mito Kaxinauá documentado por Capistrano de Abreu (4).

Este mesmo mito Kaxinauá foi registrado por André Marcel D’Ans na década de setenta (5), portanto cerca de 70 anos depois de Capistrano de Abreu. É a história da lua-cabeça, que começa com um incesto entre irmão e irmã. $\mathrm{O}$ irmão criminoso é descoberto: enquanto dorme, a irmã, que não sabia quem era o seu visitante noturno, o pinta no rosto com jenipapo - uma tinta indelével - e, ao anoitecer, a identidade do namorado é revelada. O moço foge para o mato e é morto por um grupo de anões inimigos. 
Sua cabeça é cortada e os anões divertem-se com ela, pois continua viva, mesmo sem o corpo, fazendo esforços para fugir das flechas que the atiram. O cunhado do irmão incestuoso salva a cabeça, mas esta o persegue, não o deixa mais em paz. Depois de muitas peripécias, o cunhado consegue refugiar-se na aldeia.

A mãe do morto-cabeça o convence a ir embora, pois uma cabeça isolada complica muito a vida dos homens. A cabeça decide subir ao céu por um fio que pede à mãe, e quer transformar-se em alguma coisa que não sabe o que é, que os homens não utilizem. Depois de pensar em muitas possibilidades, escolhe ser a lua. O fio pelo qual subiu vai virar o arco-íris. Ninguém poderia dizer o nome da lua nem do arco-íris, ou apontar para o céu; mas uma mulher desobedece, apontando a lua, e desde então as mulheres menstruam; um homem desobedece, nomeando o arco-íris, e desde então existe a morte.

Nas versões registradas por Capistrano de Abreu, não há o incesto - o dono da cabeça morre numa aldeia inimiga, num caso, noutra variante é uma moça que não quer se casar que é decapitada pela mãe.

\section{A cabeça voadora e Lévi-Strauss}

Se Mário de Andrade tornou a assombrosa cabeça voadora familiar, é com Lévi-Strauss que percebemos como um mito, à primeira vista excêntrico e estrambótico, é apenas uma ponta, um nó, um fragmento de um verdadeiro caudal de histórias semelhantes, transformações das primeiras, com inovações, inversões, oposições diversas de partes dos mitos, mas que inserem num todo o que parecia feérica imaginação isolada.

Uma boa parte da Origem das maneiras de mesa e da Oleira ciumenta (6) dedica-se à cabeça decapitada. Lévi-Strauss não está interessado em interpretar qualquer mito separadamente; o que lhe interessa é o conjunto, as transformações dos motivos de um mito para outro, a linguagem dos mitos entre si, a estrutura dos mitos composta das mesmas oposições com sentidos e posições diferentes; mas é a cabeça cortada que, como a lua em que se metamorfoseia, ilumina seus livros.

\section{A Origem das maneiras de mesa}

Na Origem das maneiras de mesa, o mito central é Tikuna, relatado por Nimuendaju. A personagem principal deste mito é um caçador que se casa com animais sucessivos, cada um virando mulher a seu turno: uma rã, um verme ou minhoca, uma arara. A mãe do rapaz sempre o atrapalha e, de um jeito ou de outro, faz a nora desaparecer. O mito conta como o herói, depois de três casamentos, de caçador se torna pescador quando galhos de árvores que corta se transformam em peixes. Já pescador, empreende com o cunhado uma viagem 
em piroga, em busca da terceira mulher que virou arara novamente. Conseguem encontrá-la, mas ela se transforma num monstro aquático.

Sua quarta mulher é humana, não animal; é esta que se divide, durante o dia, e a metade superior do corpo se atira à água para pescar, enquanto a metade inferior fica esperando na margem do rio. A mãe do herói mais uma vez perturba a harmonia do casamento do filho: ao descobrir a metade do corpo da nora estendido, arranca-lhe a medula. Quando a moça volta, não consegue se reconstituir e fica presa a uma árvore; ao ver o marido, gruda nas costas dele e não o deixa mais em paz, até que ele a engana, dizendo que deve ir pescar piranhas sozinho; para não ser devorada, ela se aparta e fica esperando; acaba se transformando em um papagaio tagarela.

De maneira artística, Lévi-Strauss detém-se em relações internas desse mito, que mais tarde permitirão entender outros: a relação alimento-excreção (pois é urinando e defecando que o herói engravida as duas primeiras mulheres - a rã e o verme - e as duas outras o alimentam com produtos da roça e com peixe), a agricultura-caça-coleta, a endogamia ou exogamia (casamento exogâmico com animais, endogâmico com uma mulher), a proximidade ou distância entre os cônjuges.

A viagem na piroga vai permitir-lhe, mais adiante, relacionar este mito com outros sobre sol e lua, que falam de outras pirogas (uma delas maia-quiché), que têm os dois astros pintados na quilha. Como noutras histórias sol e lua são esposas ou maridos, será possível refletir sobre a distância ou proximidade impensável entre marido e mulher.

\section{A metamorfose na esposa grudenta}

Muitos outros mitos nos quais a cabeça voraz transforma-se na mulher grudenta, como na história Macurap, aparecem ao longo do livro. Um mito Uitoto amazonense (7) conta sobre espíritos que mutilam e reunificam cada noite o corpo da mulher de um caçador. Este os surpreende e eles abandonam a vítima sem colá-la - a cabeça, então, cola-se ao corpo do marido, para castigá-lo por haver desafiado os espíritos. Quanto a ela, vira um papagaio.

Num mito Warrau (8), um caçador enfia uma flecha nas órbitas de um crânio humano; trata-se de um espírito maligno que gruda nele. Um mito Shipaia (9), relatado por Nimuendaju, fala de uma mulher cuja cabeça, à noite, se separa do corpo; gruda no marido, mas ele consegue livrar-se dela.

Num mito iroquês, um homem salva um doente que gruda nele - o herói acaba se enforcando junto com seu alter-ego, como única forma de livrar-se dele, mas falha, um cachorro impede sua morte e a de seu duplo. Um mito Assiniboine conta de um rapaz que recusa todas as noivas; para vingá-las, uma velha feiíssima 
gruda nele e só consegue soltar-se quando promete casar com a mulher que o libertar da velha (10).

\section{Da mulher colante ao pênis alongado}

Entre muitos outros mitos, Lévi-Strauss passa às rãs que viram esposas grudentas. Um curioso mito Munduruku (11), contado por Murphy, fala de uma mulher-sapo que prende um homem na vagina ao se transformar em $\mathrm{mu}$ lher e seduzi-lo. Ela pede que ele a avise antes do orgasmo; ele obedece e sai, mas o pênis fica preso, e se alonga. A mulher-sapo o solta, mas seu pênis compridíssimo deve agora ser enrolado em volta de si para que possa andar. São as lontras que o curam.

Aparentemente este mito nada tem a ver com a cabeça cortada, mas LéviStrauss arrola muitos outros sobre pênis alongados gigantescamente, testículos Eskimó longos, pênis mutilados, pênis Tacana alongado indo até a lua (12). Pênis longo e mulher grudenta, segundo o pesquisador, sugerem valores simétricos, pedaços grudados.

\section{Astros e mutilação corporal}

Uma grande seleção de mitos sul e norte-americanos, cujas intrincadas relações entre si vão sendo demonstradas, são utilizados por Lévi-Strauss para indicar como a mutilação corporal está ligada ao aparecimento de constelações, astros em geral, por vezes sol e lua. Em alguns destes ou noutros mitos, o papel da cabeça cortada grudenta é assumido pelas rãs.

Toda uma vertente nessa direção pode ser exemplificada por um mito Hidatsa, ou um Arapaho muito semelhante, sobre as esposas dos astros (13). Nele, Lua e Sol, irmãos, resolvem se casar. O sol acha que as rãs são mais bonitas que as mulheres, porque estas não conseguem olhá-lo durante o dia; com a luz excessiva, ficam cheias de rugas, apertando muito as pálpebras e ele nem consegue ver se são bonitas porque o evitam, virando o rosto. A Lua prefere as mulheres Hidatsa.

Resolvem levar para sua casa uma mulher e uma rã, para compará-las. A Lua rapta uma jovem Hidatsa, que subira numa árvore para perseguir um porcoespinho (no qual a própria Lua se transformara) e o Sol leva uma rã para o céu.

Nos céus, há um concurso de mastigação para ver qual das duas esposas faz o melhor barulho. A mulher humana de Lua come bem, mastiga com ruído; a rã apenas mastiga carvão e baba, sujando-se. Lua, irritado com a cunhada, joga-a no fogo, mas ela pula e gruda nele, afirmando que nunca mais o largará. Desde então a Lua tem as manchas pretas na face iluminada que vemos, que representam a rã colada em seu rosto. 


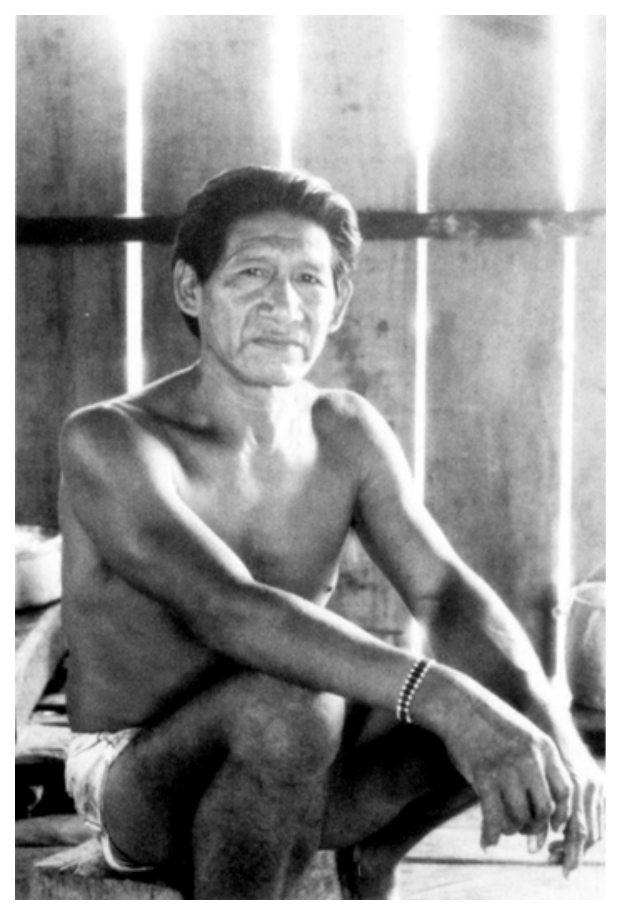

Anisio Aruá

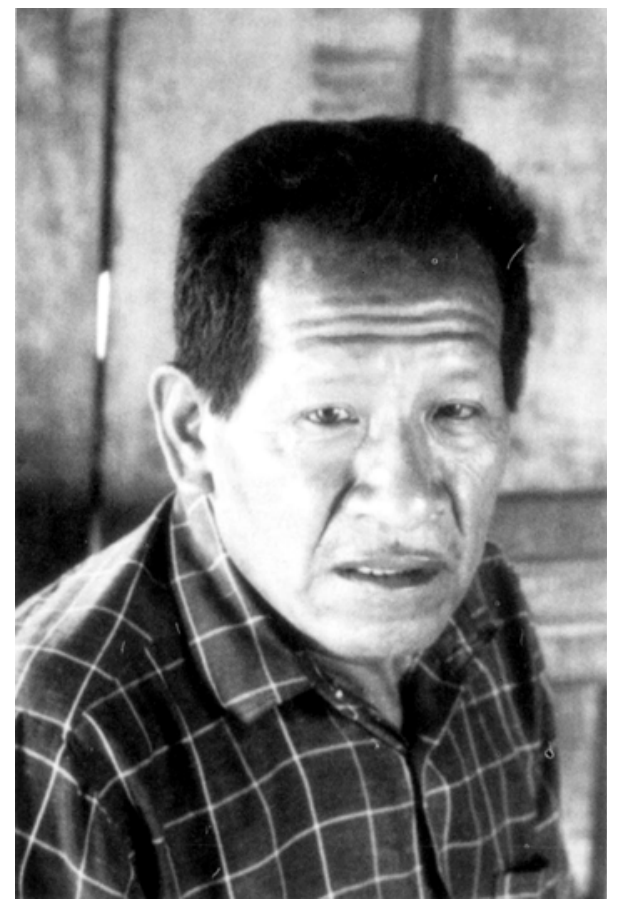

Maetsin Tupari-narrador

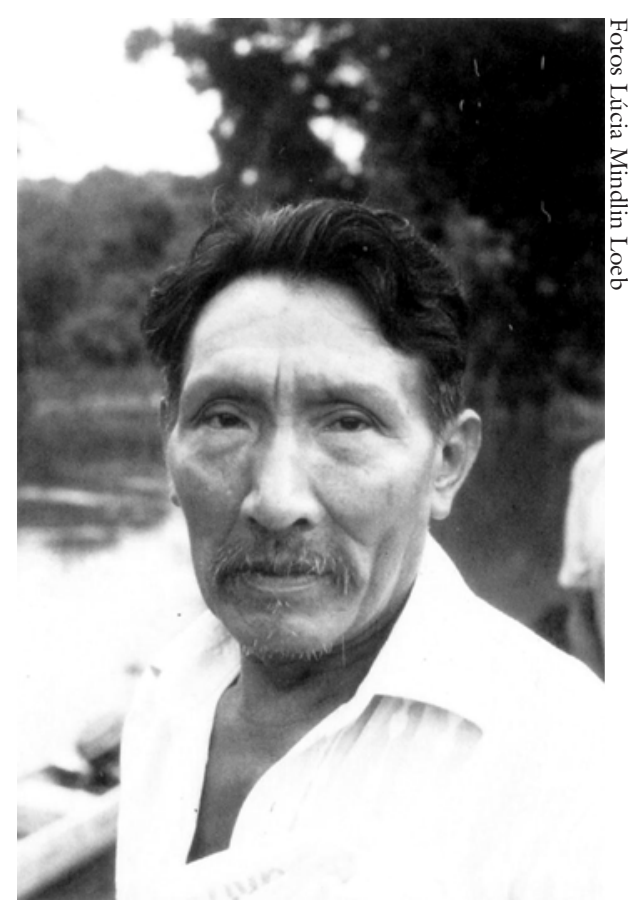

Konkuat Tupari-narrador

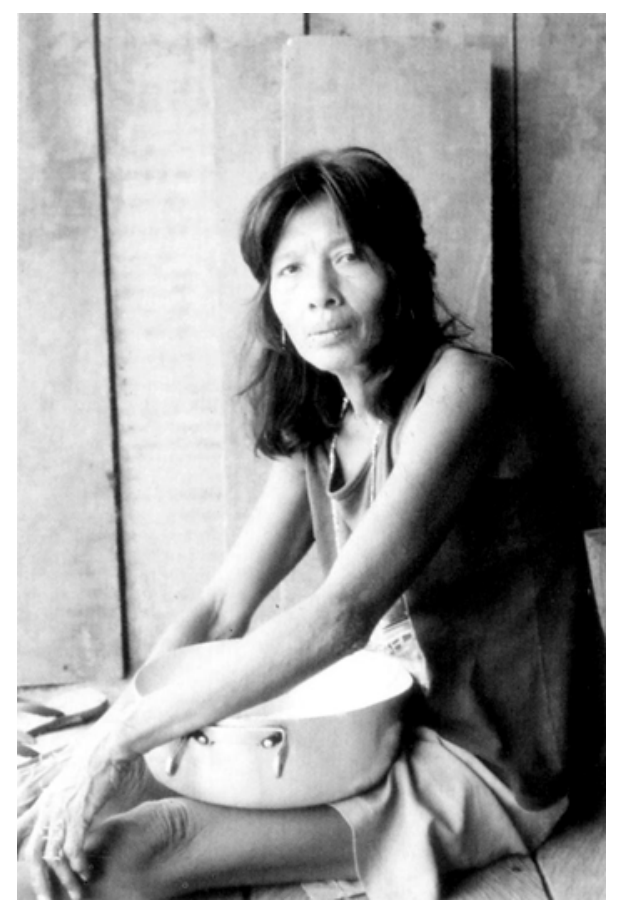

Rosa Macurap 


\section{A Oleira ciumenta}

Na Oleira ciumenta, mais ainda juntam-se a cabeça voadora, a esposa grudenta e o engole-vento ou bacurau. O livro gira em torno de um mito Jívaro em que Sol e Lua são casados com uma mesma mulher, a Engole-vento. Esta gosta do Sol, quente, mas tem medo de Lua, que é muito frio. Lua, humilhado, foge para o céu por um cipó, não sem antes soprar o sol, eclipsando-o. A mulher Engole-vento fica, assim, sem marido algum. Vai para o céu atrás deles, levando um cesto cheio de argila, mas Lua, para se livrar dela, corta o cipó pelo qual ela subia. A argila se espalha pelo mundo. A mulher transforma-se no pássaro que tem seu nome, chorando sempre nas noites de lua.

Até aqui, o elo com as histórias Macurap e Tupari é o engole-vento e, se pensarmos nos outros mitos, o Sol/a Lua, a figura da mulher grudenta, por vezes a rã.

\section{Caráter soturno do engole-vento}

O engole-vento, pássaro com enorme boca, que vai até suas orelhas, engole insetos grandes como a mariposa e é, segundo Lévi-Strauss, ligado à morte e ao mundo subterrâneo - às vezes com conotação positiva, pois, como lembra, Léry escreve que os Tupi achavam que os engole-ventos trariam boas-novas de parentes mortos.

Lembra ainda que no Popol-puh - livro sagrado dos Maia-quiché - os pássaros noturnos guardiães do reino infernal seriam provavelmente os engoleventos; e para os Tikuna, as almas dos mortos voltariam sob a forma de engoleventos, espíritos maléficos sugadores de sangue e devoradores de carne e de ossos dos vivos (14). Lembra também que há uma crença européia de que são suga-cabras (o nome da ordem é caprimulgiformes) e sobrevoariam rebanhos para sugar o leite. Nada poderia combinar melhor com o bacurau do mito Tupari, descendo para um repasto com os cadáveres assassinados...

\section{O ciume e a gula: excesso}

A partir do mito Jívaro, Lévi-Strauss acentua como o ciúme conjugal é característica dos engole-ventos (se Sol e Lua soubessem dividir bem a mulher engole-vento, nada teria acontecido): "O pássaro aparece em primeiro plano nos mitos cujo tema é a separação ou desentendimento entre os sexos, devido ao ciúme entre dois homens com relação a uma mulher, ou ciúme de um ou uma amante rejeitado(a), ou ainda à impossiblidade da união de dois amantes, ou aos desentendimentos de um casal. Mesmo nos mitos em que o engole-vento aparece como autor ou resultado de uma decapitação, os motivos mencionados não estão totalmente ausentes: a decapitação também acarreta uma separação. Como o casal separado, a cabeça ou o corpo desligados um do outro sofrem a perda da outra parte" (15). 
Mais adiante, a Oleira ciumenta, em uma série de mitos, vai dando ênfase à oralidade, à avidez e à gula como atributos fundamentais dos engole-ventos. Num mito Kayapó (16), "um marido malvado trata a mulher como escrava, e proíbe-a de comer carne e de tomar água. Durante a noite, ela sente uma sede terrível. Sente vontade de aproveitar enquanto o marido dorme e ir ao lugar onde as rãs coaxam, sinal de que lá deve haver água; mas teme que o homem descubra a sua ausência. Então ela tem a idéia de se dividir em dois pedaços; o corpo ficaria ao lado do marido, e a cabeça voaria, usando os longos cabelos como asas, para matar a sede. Mas o marido acorda, percebe o truque da mulher e espalha as brasas da fogueira. A cabeça não consegue encontrar o caminho de volta para a casa, agora às escuras. Voa a noite toda em busca de seu corpo, enquanto o marido o assa. Continuando a voar, transforma-se em Engole-vento. Passamos assim do motivo do guloso ou da gulosa egoísta para o da decapitação."

Juntam-se aí a cabeça decapitada, o engole-vento e, tenuemente, pela menção às rãs, a mulher grudenta.

\section{O riso, o alimento, o excremento}

Um mito Tikuna é evocado como outra forma de explosão ou avidez do engole-vento; foge um pouco ao tema, mas é muito engraçado. Só uma velha possuía o fogo, e o recebera do engole-vento que o guardava dentro do bico. Os índios, curiosos, perguntam à velha por que ela cozinha tão melhor que todo mundo; ela responde que cozinha o beiju com o calor do sol. O engole-vento acha tanta graça na mentira da velha que explode de tanto rir; os homens avistam o fogo e rasgam sua boca à força (para pegar o fogo, explicação do tamanho escancarado da boca dos engole-ventos para os Tikuna).

Segue a Oleira ciumenta por sendas fascinantes, contrapondo o ávido engole-vento ao preguiça econômico que come e evacua pouquíssimo, com longos intervalos, ou ao joão-de-barro, sempre próximo e em diálogo permanente com a esposa, alegre, ao contrário do engole-vento soturno e partido, separado do cônjuge e explosivo. Analisa, entre outros temas, alimentos e excrementos estes separados do corpo como pedaços mutilados, transformados por vezes em astros ou cometas.

\section{Outros ramos de $A$ cabeça voraz}

O prazer de ler e ouvir uma história tão pouco usual como $A$ cabeça voraz já é grande, mesmo quando faltam outras informações ou uma visão de conjunto. A perplexidade é parte do encanto; é o imprevisto das imagens.

Percebemos que poderíamos compreendê-la muito melhor se soubéssemos o que esta sociedade - que conta os mitos - conhece sobre astronomia, 
botânica, zoologia, como se organiza e quais são os seus hábitos, se entendêssemos bem a língua da narrativa. Apesar desta ignorância, quanto mais histórias ouvimos, mais elas nos prendem como uma obra de ficção e vão se tornando familiares, com seus enredos que espantam e acordam estranhos ecos.

Certamente, uma das atrações de ouvir ou ler uma quantidade maior de mitos é reconhecer que fazem parte de uma vasta raiz, indígena, local ou universal - daí o fascínio de uma teoria sobre a estrutura da mente humana, como a de Lévi-Strauss -, de uma fonte oculta que parece infinita, misteriosa, mas ao mesmo tempo vai se desvendando passo a passo. Ler ou ouvir espontaneamente cada história, mergulhando, tentando apanhar o significado restrito do que está ali inserido, fruindo a forma e o estilo - ao mesmo tempo voar pelas analogias e ligações com outros mitos, que indicam um sentido mais amplo.

Entre os mitos de Rondônia, muitos outros tornariam ainda mais densa $A$ cabeça voraz. É uma pena resumir os mitos, contados com tanta arte, mas não há outro jeito se tentamos costurá-los com fios diversos.

\section{O sexo sem homem}

Uma história Tupari, por exemplo, conta que uma moça solteira não gostava de homem algum e fizera para si um pênis de barro, com quem namorava como se fosse um homem de verdade. Um dia, umas espécies de lacraias, que na região são chamados de emboás, cheios de pernas, enfiaram-se no oco do namorado de barro da moça, ficaram dentro de sua barriga no quentinho, chupando suas entranhas, e enchendo-a de emboás, como se estivesse grávida, sem ter namorado homem algum. Ela teve o maior trabalho para livrar-se deles todos, tinha de sentar-se em orelhas-de-pau, que os emboás gostam de roer, para que eles saíssem. Desde então, diz a narradora, nunca mais ousou usar o seu instrumento de barro.

Noutra história Tupari, uma moça reclusa, por estar menstruada, namora uma cobra-cega, espécie de minhoca. Engravida, a barriga vai crescendo, pinicando e atormentando-a de dor. Os filhotes nascem por todos os buracos de seu corpo e ela morre.

Num mito Kaxinauá (17) uma linda moça que não quer se casar namora um verme às escondidas. Engravida, o ventre vai crescendo e a mãe da moça descobre tudo e mata o verme... Tristíssima, a moça foge para a floresta para ser devorada pelos jaguares. Mas um jaguar se transforma num guerreiro lindíssimo, com magníficas flechas pintadas, nas quais haviam se transformado suas garras. Promete curá-la e tirar os vermes de dentro dela. Ela deve deitar na água corrente, abrir as pernas sem jamais tentar fechá-las, enquanto o jaguar bate timbó. Os vermes vão saindo, numa cena horrível, transformando-se em cobras. No final ela não agüenta e fecha as pernas - por isso até hoje temos vermes. A história 
continua, longa, acompanhando a vida da moça e suas desventuras entre os jaguares.

Um mito Wayãpi, da Guiana, junta este assunto ao da cabeça voadora (18). É a história das Plêiades ou da mulher de brincos. Uma mulher casada, ao ralar mandioca, brinca com um verme, toda feliz, namorando, rindo sozinha e engravida. Nascem dois peixes. A mãe da moça, horrorizada, pega-os para cozinhar na pimenta, num momento em que a moça sai, e dá para ela comer. A moça, sem saber de nada, come, e quase morre com o ardido da pimenta. Corre para o rio para beber água, mas tropeça, cai, e sua cabeça desprende-se do corpo... mas volta e cola-se ao pescoço outra vez.

Um dia, seu marido vai queimar a roça nova, e ela tem sede. Ele a manda ao rio para beber: a cabeça vai sozinha. O marido fica bravo ao ver o corpo sozinho, e joga-o na fogueira da roça.

Quando a cabeça volta, gruda-se às costas do marido. Ele só consegue livrar-se dela quando a convence que deve subir sozinho a uma árvore para colher frutos; atira os frutos com força na cabeça lá embaixo. De tanto levar as pancadas dos frutos, a cabeça não consegue sair do lugar, e o marido foge. Passa uma anta, e a cabeça gruda-se no animal. A anta morre; a cabeça fica ao lado, esperando a chegada das aves de rapina, mas passa outro pássaro (daguet rouge). Ela gruda-se a esse pássaro, que morre. Ela fica ao seu lado; vêm as aves de rapina, a cabeça gruda-se ao pescoço delas. E vai com elas para o céu, mas lá, salta e se agarra ao céu. E seus brincos se transformam, com ela, na constelação das Plêiades.

\section{A domesticação das mulheres}

Com razão insiste Lévi-Strauss, nestes livros e em outros, sobre a função de educação das mulheres que têm estes mitos: o que a mulher deve ou não fazer, seu papel ideal, qual o comportamento prescrito nos rituais de passagem, como puberdade, parto etc., quais as formas ideais de casamento, com cônjuges próximos ou longínquos como os astros, quais as transgressões impensáveis.

As histórias da cabeça-sem-corpo sobre o masculino/feminino, a voracidade e o excesso são iluminações sobre o céu e a terra, as alturas e o mundo em que vivemos, a vida e a morte. Em geral, a cabeça decapitada, grudenta, parece ser de mulher; mas há um mito Macurap sobre um marido morto que cola-se insuportável, putrefato, ao corpo da mulher viva, que a muito custo se livra dele, numa boa parábola para as viúvas ou mulheres separadas.(Também dois mitos Sateré-Mawé, que registrei em 1996, são de cabeças rolantes de homens, sendo um deles um homem adúltero. Vimos que o mito Kaxinauá também se refere a uma cabeça rolante masculina). 
Eis aí quase que historinhas morais para ditar o comportamento esperado ou proibido nas mulheres. Buscar o prazer sexual sem ser com o marido; pior que isso, até sem os homens, com a solução extrema de recorrer a um verme ou a um bastão de barro, livrando-se das exigências sociais, de trabalho e de conduta que a sexualidade e o afeto ditos normais impõem, eis o crime, ocasionalmente criativo porém, pois pode redundar no aparecimento de um astro.

\section{Revivendo o emaranhado}

Ir buscar os fios invisíveis que ligam a outros esses mitos misteriosos talvez possa contribuir para torná-los mais vivos, circulando, exibindo sua capacidade inventiva, realizando seu potencial de "despertar no homem os pensamentos que lhe são desconhecidos", como diz Lévi-Strauss em Mito e significado, inspirando a ficção moderna.

Com Lévi-Strauss, principalmente com O pensamento selvagem e com as Mitológicas, os mitos indígenas passaram a ser vistos como respeitáveis, o universo indígena apreciado com o mesmo estatuto que a ficção e a mitologia de outros povos, como a grega clássica ou a hindu. Ainda assim, a leitura de mitos continua sendo considerada difícil, externa aos padrões culturais mais familiares, feita mais por especialistas que por leitores comuns, que julgam não compreendêlos.

Há sempre o problema da escrita e sua forma. Só pela leitura acessíveis ao grande público, não no modo oral que é o seu próprio, os mitos brasileiros, em sua maioria, ainda não foram escritos. A escrita os transforma, muda-lhes o caráter, mas ainda assim é um registro, um instrumento contra o desaparecimento total. A transmissão da tradição oral está cada vez mais ameaçada pelas transformações e dramas da vida indígena, pela mudança de valores de gerações, nascidas em mundos diversos. Há quem pense que a escrita pode contribuir para a destruição da oralidade; mas a escrita, em si, não é um fator contrário, desde que estimule o interesse pelas raízes culturais.

É importante que o universo mítico indígena se torne mais popular, faça parte do imaginário brasileiro, seja pesquisado, deixe de ser um domínio ignoto e incompreensível. E ao mesmo tempo, que os índios escrevam, em português e nas suas línguas, publiquem muito, continuem contando oralmente, transmitindo e lembrando as suas tradições. Só assim poderá ser reafirmada a originalidade de formas de pensar tão próximas e tão distantes de nós.

Notas

1 Betty Mindlin, Tuparis e tarupás. São Paulo, Brasiliense/Edusp/Iamá, 1994, p.106107. 
2 Johan Dalgas Frisch, Aves brasileiras. São Paulo, Dalgas-Ecoltec Ecologia Técnica, 1981, v. 1, p. 122.

3 Relatos de vários narradores Macurap a Betty Mindlin, 1987 a 1995.

4 J. Capistrano de Abreu, Rã-txa hu-ni-ku- i. Rio de Janeiro, Livraria Briguiet, 1941.

5 André Marcel D'Ans, Le dit des vrais hommes. Paris, Union Générale d'Editions, Collection 1018, 1979, p.146-157.

6 Claude Lévi-Strauss, L'origine des manières de table. Paris, Plon, 1968. A oleira cinmenta. São Paulo, Brasiliense, 1986. Le cru et le cuit. Paris, Plon, 1964. Du miel aux cendres. Paris, Plon, 1966. L’homme mu. Paris, Plon, 1971. La pensée sauvage. Paris, Plon, 1962. Mito e significado. Lisboa, Edições 70, 1979.

7 Claude Lévi-Strauss, L'origine des manières de table. Paris, Plon, 1968, p.42, mito documentado por Preuss.

8 Id. Ibid., p. 43, mito Warrau documentado por Wilbert.

9 Id. Ibid., p. 43.

10 Id. Ibid., p. 45.

11 Id. Ibid., p. 65-66.

12 Id. Ibid., p. 67, índios Tumupasa.

13 Id. Ibid., p. 170.

14 Claude Lévi-Strauss, A oleira ciumenta. São Paulo, Brasiliense, 1986, p. 51.

15 Id. Ibid., p. 71.

16 Id. Ibid., p. 61.

17 Johan Dalgas Frisch, Aves brasileiras. São Paulo, Dalgas-Ecoltec Ecologia Técnica, 1981, v. 1, p.66-97, 'Le roman du tigre'.

18 Françoise Grenand, Et l'homme devint jaguar. Paris, L'Harmattan, 1982. p. 140147, 'Les Pléiades ou la femme aux boucles d'oreilles'.

\section{Resumo}

$\mathrm{o}$ artigo focaliza um mito indígena sobre a cabeça voadora e voraz, registrado pela autora em vários grupos indígenas da Amazônia, como os Tupari, os Macurap, os Jabuti, os Aruá, os Sateré-Mawé. Cada versão do mito tem um enredo diferente, mas o tema intrigante é sempre o mesmo: a mutilação do corpo, a cabeça que se transforma ou cola-se num outro ser. Procura-se mergulhar no significado desse mito, ao qual Claude LéviStrauss dedicou boa parte de dois livros magistrais, $A$ origem das maneiras da mesa e $A$ oleira ciumenta, e que foi usado por Mário de Andrade no livro clássico sobre o herói brasileiro, Macunaina, uma das poucas obras de fição brasileira a se inspirar em temas e 
personagens míticos indígenas. O registro de campo desse mito é uma pequena ponta de um amplo trabalho de documentação da tradição e dos mitos indígenas brasileiros, que a autora vem realizando há alguns anos. A intenção, nesse texto, é compreender a riqueza do imaginário indígena brasileiro, insistir na necessidade de documentar culturas que são nossas contemporâneas e ainda bastante desconhecidas. A fição e a arte brasileiras poderiam ampliar muito o seu universo ao explorar e tentar compreender as raízes brasileiras que nos são dadas por mais de 200 povos indígenas do país. Também para os índios, escrever, contar, divulgar e usar nas próprias escolas os seus mitos é importante para reafirmar a identidade étnica e valorizar sua participação na sociedade brasileira.

\begin{abstract}
The article focuses an indian myth about a flying and voracious head, that was told to the author by several indian tribes from the Amazon, such as the Tupari, the Macurap, the Jabuti, the Aruá, the Sateré-Mawé. Each version has a different plot, but the intriguing theme is always the same: the mutilation of the body, a head that is transformed or attaches itself to another being. The essay delves into the meaning of this myth, to which Claude Lévi-Strauss dedicated a good portion of his two important books, L'origine des manières de table and La potière jalouse, and that was used by Mário de Andrade in his classic book about Brazilian hero, Macunaina, one of the few works of fiction to have been inspired by mythicalindian themes and characters. Reporting this myth is just a small part of a large project of documentation of myths and traditions of Brazilian indians that author has been working on for several years. The aim of this text is to show the rich imagination of Brazilian indians, and to insist on the need to document contemporary cultures that are still widely unknown. Brazilian art and fiction could enlarge their universe by exploring and trying to understant the heritage left to us by over two hundred different indian tribes. It is also important fot the indians to reaffirm their ethnic identity, and enhance the worth their participation in Brazilian society, by writing, telling and spreading these myths, and by using them in their schools.
\end{abstract}

Betty Mindlin, antropóloga, é professora visitante do Instituto de Estudos Avançados da usp e coordenadora do Iamá (Instituto de Antropologia e Meio Ambiente). É mestre em Ciências Econômicas (Universidade de Cornell, N.York) e doutora em Antropologia (Pontifícia Universidade Católica de São Paulo). É autora, juntamente com os narradores indígenas, dos livros de mitos Tuparis e Tarupás (São Paulo, Brasiliense/Edusp/ Iamá, 1993) e Vozes da origem (São Paulo, Ática/Iamá, no prelo), traduzido para o inglês com o título de Unwritten stories of the Suruí Indians of Rondônia, (Austin, Texas University Press, 1995).

A autora agradece ao pintor, escultor e ceramista gaúcho-pernambucano Adão Pinheiro, que andando pelo mundo, entre Washington, Suíça, Olinda e São Paulo, ainda achou tempo de voar com tantas cabeças. 


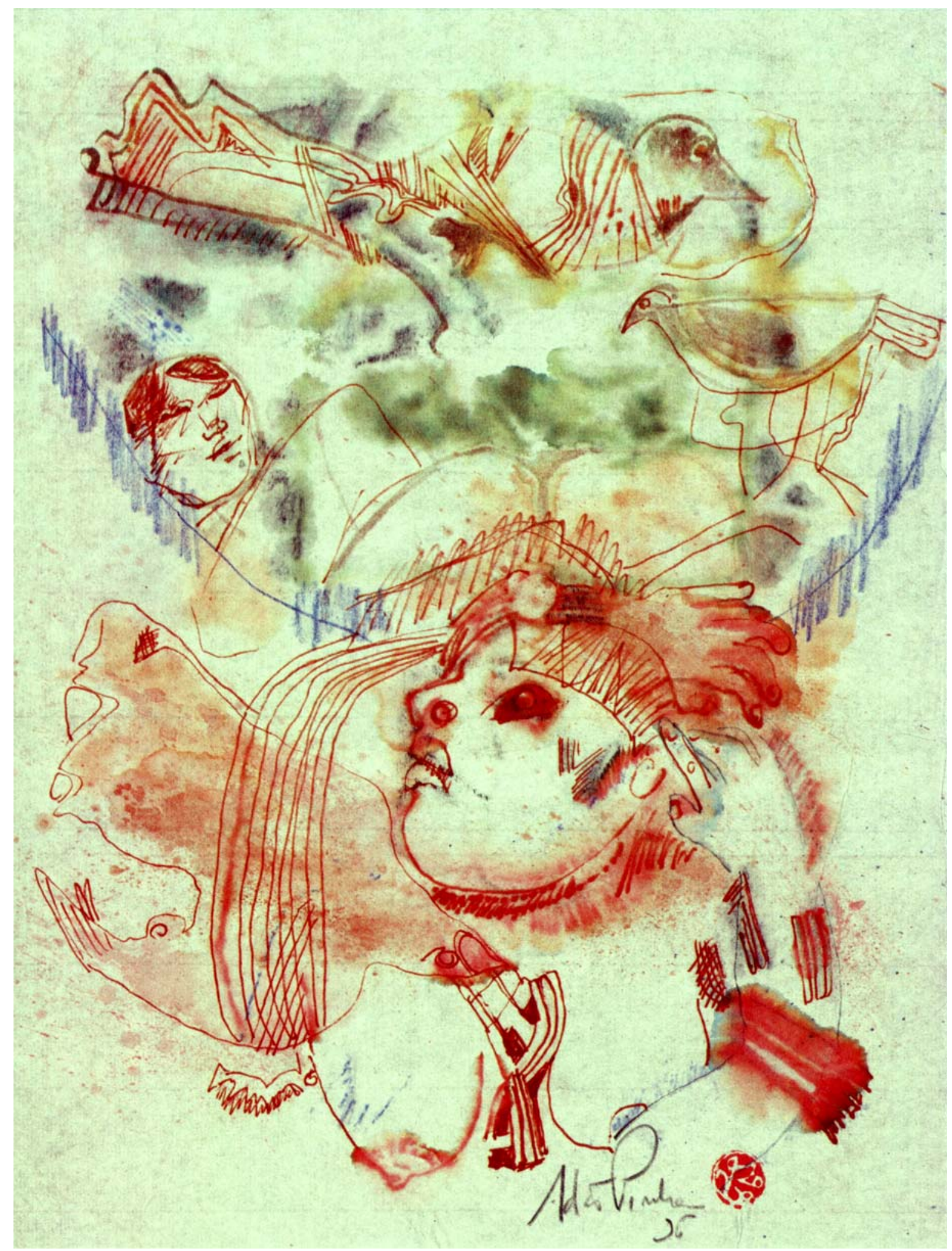

Num casal muito unido, a cabeça da mulher sai a passeio todas as noites, ávida por caça... 



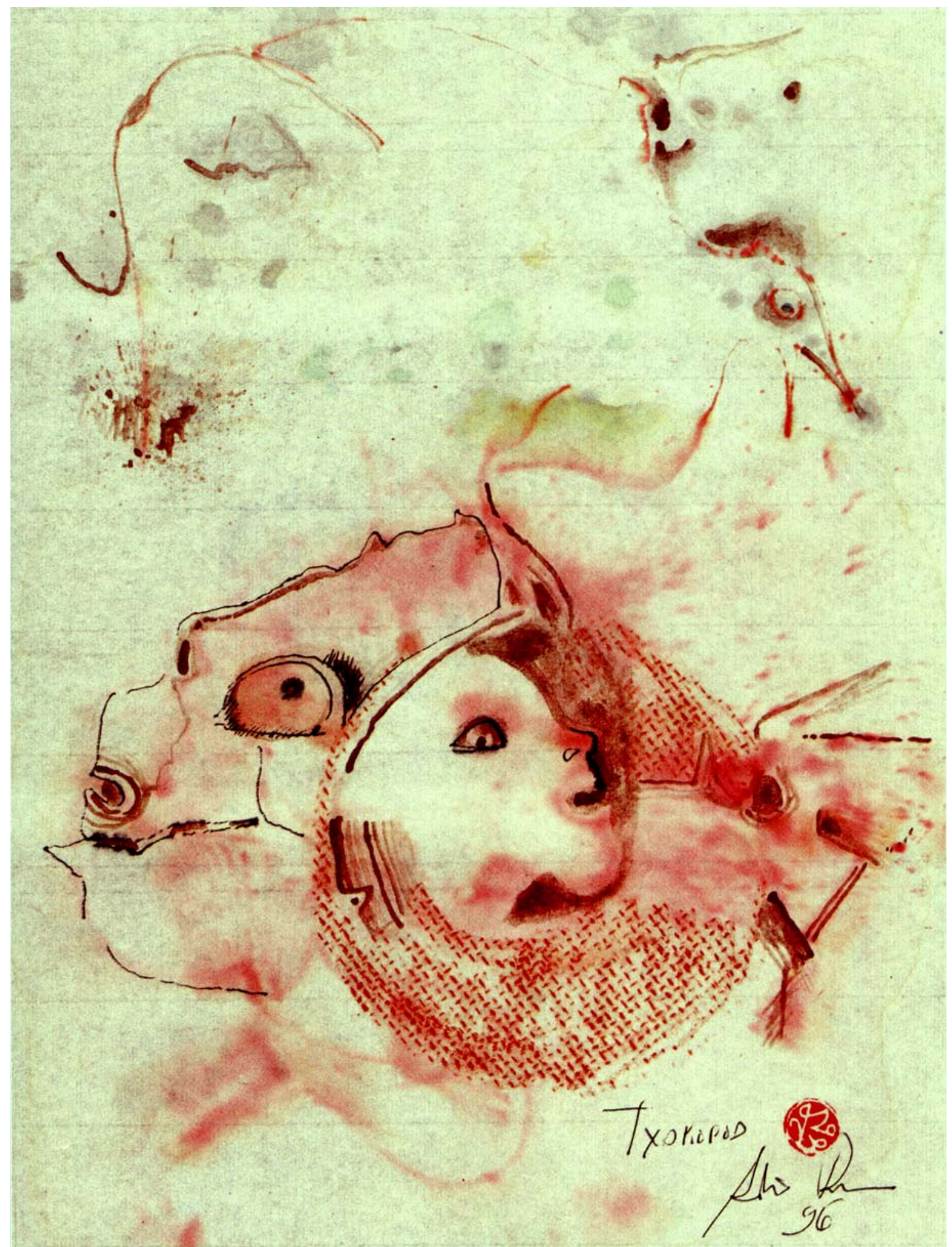

A cabeça, sozinha, fétida passa a ser um Txopokod, espirito ameaçador que devora os homens... 



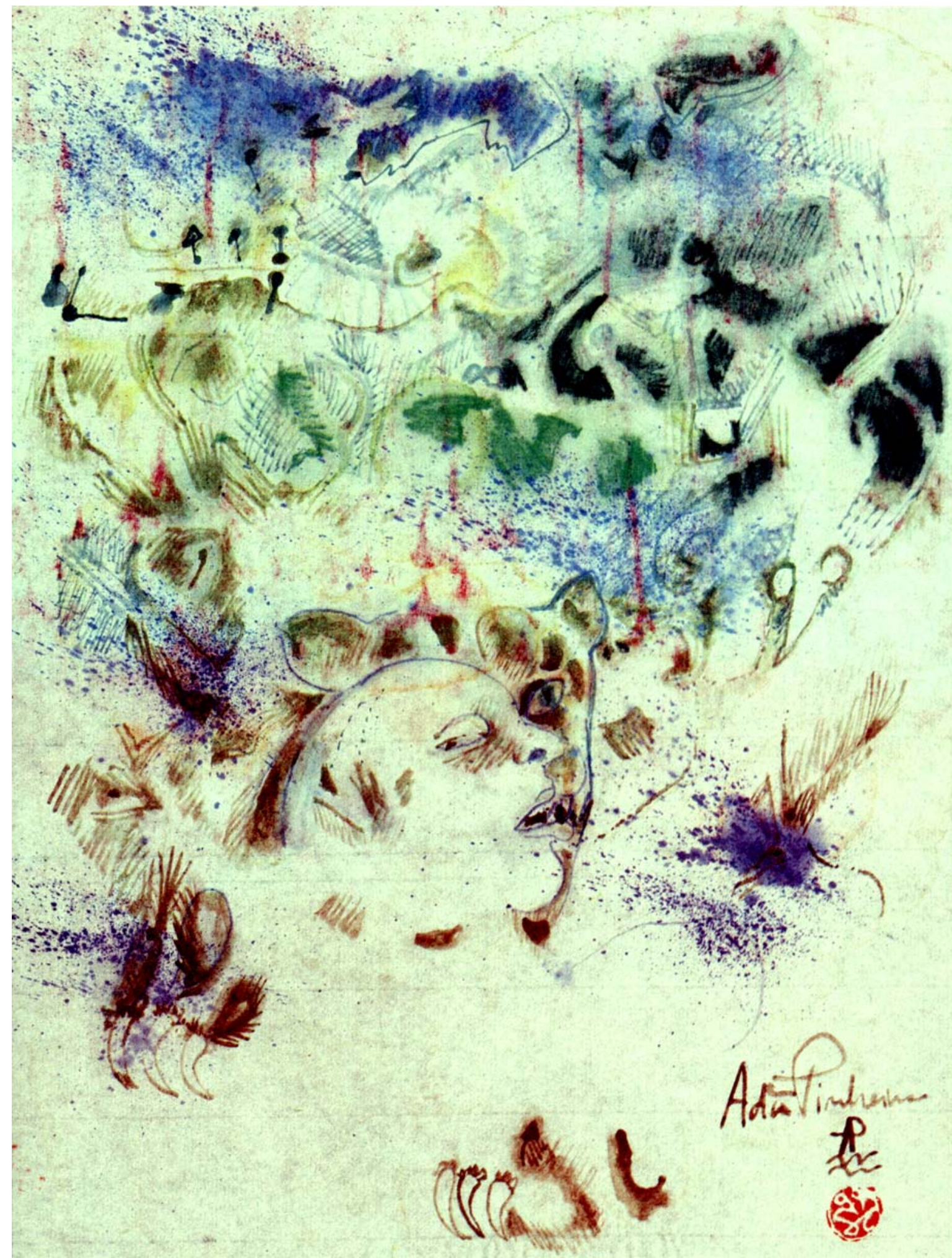

Vem nas noites seguintes, lamuriosa, chamar o marido. É agora um espirito malévolo, um Tarupá. 



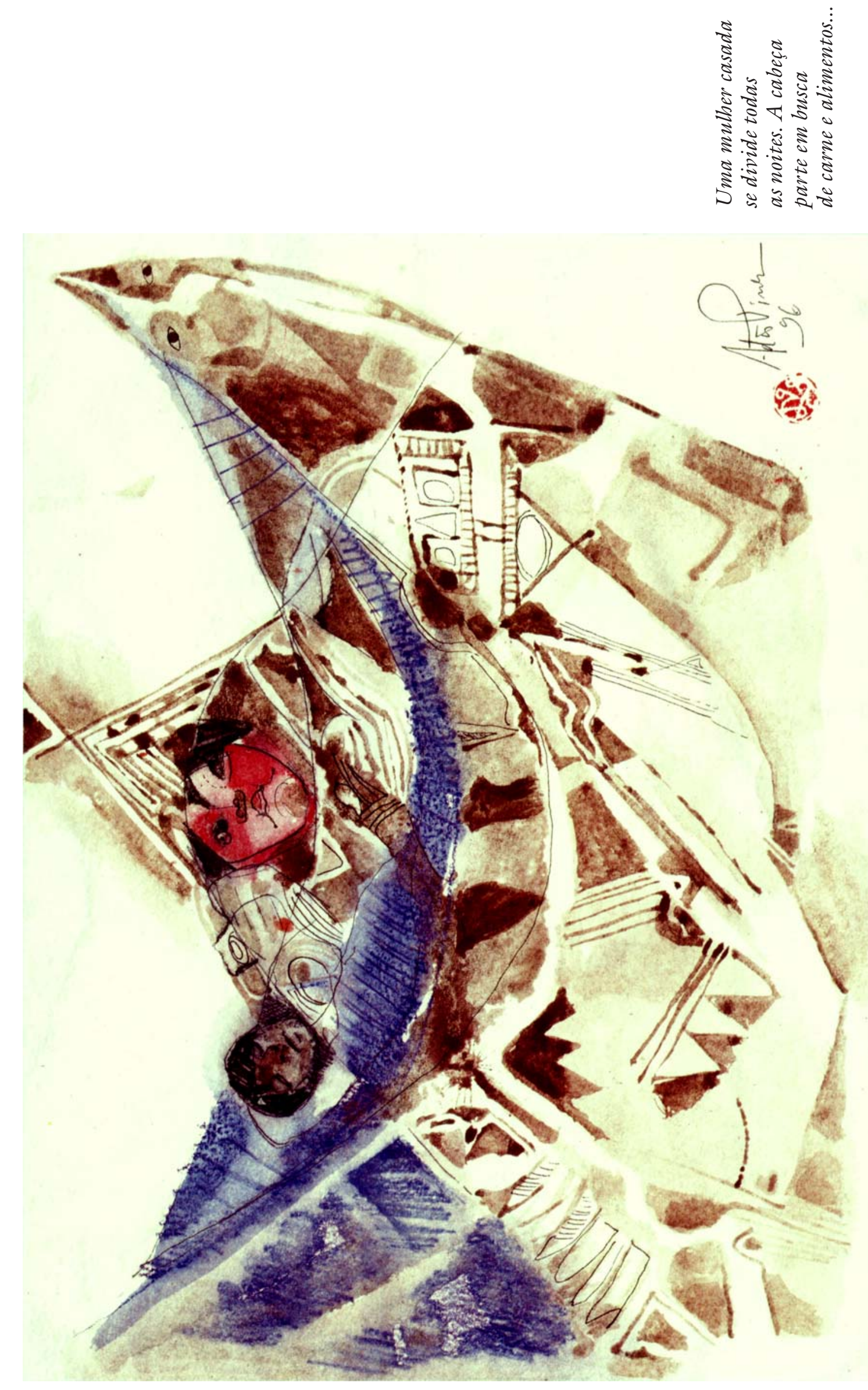

